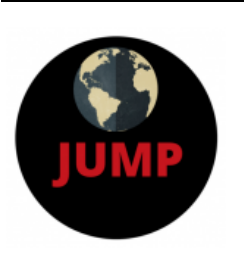

\author{
OJED \\ ISSN: 2574-3465 Print/ ISSN: 2574-3481 Online \\ Volume 4, Issue 1 (2020), pp. 85- 93 \\ (C) Journal of Underrepresented and Minority Progress \\ http://ojed.org/jump
}

\title{
The Hard Path of Becoming a Visiting Scholar in the United States
}

\author{
Margherita Daho' \\ Department of Cognitive Sciences, Psychology, Educational and Cultural \\ Studies (COSPECS), University of Messina, Messina, Italy
}

\begin{abstract}
With globalization and the continual growth of studies abroad, many Ph.D. students apply to move to other countries for an exchange experience. Many students elect the United States as their preferred destination, attracted by the perceived better quality of education. In addition, they may want to specialize in a field not offered in their home country or want access to specific laboratories of research. The United States also tries to attract international students to its colleges and universities. However, becoming a visiting scholar is very hard and takes considerable time. Applications and bureaucracy are cumbersome and major support is required, especially for international students. This article is a reflection on my experience planning an exchange experience in the United States during my Ph.D. I also offer recommendations for improving the experiences of international visiting scholars.
\end{abstract}

Keywords: exchange experience, international students, visiting scholars 


\section{INTRODUCTION}

From the first day of my Ph.D. I have heard, "Pursuing an ambitious research project with satisfying results is an essential element of every competitive Ph.D. student." An educational experience abroad nowadays is often encouraged, and in some cases even required, by academic institutions, included the one I am attending. Serving as a visiting scholar or visiting researcher is important, not only to be more competitive but also to gain knowledge, learn new or different technologies, improve personal skills, and gain new cross-cultural competencies (Dwyer, 2004; Pascarella et al., 2001; Williams, 2005). For this reason, many Ph.D. students try every year to move to other countries for an exchange experience, especially if they are pursuing scientific, technological, or business careers (Institute of International Education, 2017; Naffziger et al., 2008). Often international students elect the United States as their preferred destination because of the perceived better quality of education (Chao et al., 2017; Hefner-Bab \& Khoshlessan, 2018; Marks et al., 2018). Furthermore, they want to specialize in an area that may be not offered in their home country or they want access to specific laboratories of research (Chao et al., 2017). As an international student, I agree with these findings. However, I also add that the hundreds of movies and sitcoms set in typical American colleges that are watched internationally since childhood may contribute to the desire to live a similar experience. This hypothesis has never been empirically explored, and it would also be very hard to demonstrate a correlation, as this movie-influence probably works on an unconscious level.

Human Resources No.110-73 of 2007 (cited in Hefner-Babb \& Khoshlessan, 2018) stated that the United States has in recent decades tried to attracting international students to its colleges and universities. In addition, the internationalization of colleges is a growing global opportunity both economically and politically for the host countries (Zawacki-Richter \& Bedenlier, 2015). In fact, international students contribute to increased trade and investment opportunities (Skinner, 2009) and to maintaining positive relations among countries (Nikias, 2008). Skinner (2009) asserted also that in the last 30 years the United States has been trying to originate an international education policy to facilitate the process. For instance, they tried to ease visa requirements, modify high-priced tuition costs, and increase scholarships for international students. However, Human Resources No.11073 of 2007 (cited in Hefner-Babb \& Khoshlessan, 2018) and more recently Fisher (2017) reported that the visa policies of the American embassies in foreign countries are often a barrier for international students. Recently, another study (Springer et al., 2017) underlined also that the college 
admissions process has become more challenging in comparison to one decade ago.

\section{MY PERSONAL EXPERIENCE}

During my Ph.D. program, I started to work on an ambitious project regarding the moral reasoning of clinical ethics consultants. The project also included an experiment that involved both American and European subjects, in order to make a comparison. Given that I had already lived and worked in the United States, especially on the East Coast, I wanted to pursue further study there. I also had many helpful contacts. Subsequently, I left my country and returned to the United States in May 2018 to find a professor interested in the project who could sponsor me. I did not receive any reimbursement from my institution for this travel but I was successful in finding what I was looking for. Later, my application as a scholar was accepted and the professor who kindly decided to sponsor me declared that she was looking forward to working with "such a talented student" given my impressive resume. Finally, we decided to write an agreement with explicit expectations and roles to add clarity to the contract. This was only the first step of a great and long partnership between two important academic institutions. Unfortunately, they told me I had to wait almost 1 year before beginning because of the extended bureaucratic procedure. Then, 2 months before departure, the professor sent me a bleak e-mail saying that she could not sponsor me any longer because of family problems.

I never heard from her again, and I have not been able to find another professor. Even though she had already started the last final important document (the formal letter of invitation of the school for the visa application), no one in her department agreed to substitute for her (temporarily, or to complete the paperwork). The director of my school sent a formal letter to the dean of this institution with the hope to highlight the issue and help me, but the dean has not responded either. I was not looking for full-time mentoring but only for general collaboration, supervision, and sponsorship. In fact, a multidisciplinary team composed of other external Americans experts would have supported me. Furthermore, everything was ready for my departure and had been planned: classes to attend, the next steps of the research, where to live, etc. I needed to interview many subjects and wished to conduct an experiment with the use of a neuroimaging technique.

In total, I contacted 39 professors from six different states (in alphabetic order, California, Connecticut, New York, Massachusetts, Minnesota, and Rhode Island) I wrote to their official academic address between Fall 2018 and Winter 2019. First of all, I emailed those who were working in the same 
department and school that I supposed to attend so I could avoid starting a new application or restarting the long demanding bureaucracy work. Moreover, they knew their colleague well and they had similar research interests. Later, I extended my search to institutions and labs based in other American states that could support my research. Some of the keywords I used during a first selection were "moral reasoning", "decision-making process", "clinical or medical ethics." Secondly, I carefully chose only those who were working or had worked recently on projects similar to mine.

In my e-mails, I attached my resume and a brief presentation of my project. I also explained the situation of the professor who suddenly could no longer help me, and communicated that I was at risk of losing my Ph.D. and scholarship. In order to be promoted to the next year, I had to demonstrate evidence of my research advancements to a commission. In addition, I needed to leave soon because in my country the Ph.D. lasts only 3 years and I was already attending the second year (extension of the program is not possible except for health issues). Finally, a research experience abroad was a mandatory commitment.

Of the faculty members contacted, $60 \%$ did not respond, and $15 \%$ of them replied very late (over 2 weeks later or after a reminder that was sent to all those who did not reply in 2 weeks). Although the situation was delicate, their feedback most of the time was disconcerting and unsympathetic. They replied that they did not have time for supervising and meeting me even once per month, or that they did not want to give extra work to their administration office who would manage the paperwork. Almost no one apologized for the rejection, gave more detailed explanations, tried to be helpful (perhaps suggesting another academic member or lab), or showed sympathetic feelings for my situation.

\section{CONSIDERATIONS}

\section{The Discriminative Factor}

As already stated, American colleges in the past have promoted the applications of international students no matter their cultural, religious, or racial backgrounds. However, on January 27, 2017, President Trump issued an executive order prohibiting entry of citizens from seven Muslim-majority countries, and severely restricting the admission of refugees, into the United States. As a consequence of that, according to the study of Rose-Redwood and Rose-Redwood (2017), international students are increasingly becoming the targets of violence and discrimination based on their race, religion, ethnicity, and/or national origin. I wonder if the change of mind from the institution, or the lack of answers from the other professors, may have occurred because of my surname origin (not typically Anglo-Saxon or 
European) and cultural background. The question I asked myself at one point was: if I had instead a typical Italian, French, German, or English surname, would they have behaved or answered me differently?

\section{Lack of Support for Non-Degree Students}

American colleges have often hosted numerous international students: Why does it take so long (generally a full year) to accept a graduate student who is not seeking admission to a degree program? It is not hard to obtain a J-visa. Furthermore, I often had to explain to professors about the procedures of sponsorization. The institution that first accepted my application is one of the biggest in the country and the school has a history of hosting visiting scholars, so why were they so disorganized and confused about procedures?

It seems to take an unreasonable amount of time before formalizing an admission as a visiting scholar. I was supposed to audit classes, had to pay personally my visa tuitions (over $\$ 1000$ ), medical health insurance fees $(\$ 250$ per month), and other administrative fees (\$160 per month), without any contribution from the hosting of the home school. Full-time international students who are enrolled do not as much time before obtaining formal admission and starting to attend classes, although they require more attention from the institution. (Schools typically support international students with health insurance, fees/tuition, scholarships, advising, or tutoring activities, etc.)

\section{Application Successfully Accepted}

Initially, my application was accepted and the hosting school gave permission to start my visiting stay. However, after the professor could not support me, I think the university should have found a substitute for her, given that I had been accepted as a potential student, but they did not. What if this event had occurred when I already had my visa or left my country? Would they have forced me to return home? Would they have left me alone without assistance because no other academic members could or wanted to supervise my project? Unexpected events and issues happen and institutions should be ready to find fast solutions.

\section{Agreement Not Respected}

A written agreement between two academic institutions is always recommended. In this case, the written agreement had not been finalized before the professor backed out of sponsoring me. However, some faculty members knew about this established expectation. I think that given the 
mutual interest by both institutions to collaborate and establish a long-time partnership, the process could have continued anyway.

This American school has lost not only the possibility to host a talented student and to collaborate on an important international project they were interested in, but it has also lost the opportunity to give their students and academic members an experience of cultural exchange. Indeed, the written agreement that both institutions were formalizing, included also the possibility to exchange and host reciprocally visiting students, researchers, and professors. A second written agreement between the host professor and the scholar student has been made instead, and it respected the desires and expectations of each. This agreement should have been respected and the opposite is not ethically acceptable.

\section{CONCLUSIONS}

In the process of attempting to find a supporting institution and faculty, I experienced very few responses, and those who did, cited a lack of time to support me. Professors and academic staff did not collaborate well, also showed a lack of empathy, and seemed uninterested in cultural exchange. The situation provoked in me strong feelings of sadness, anxiety, stress, and frustration for months, especially because I was at risk of losing my doctorate student status and scholarship, which is also my unique income. The administrative staff could also have shown more compassion and been more collaborative. A nice word or advice would have made the difference for me, as I would have felt less alone and I would have been more positive. Furthermore, racial prejudice or discrimination may have been a reason for this rude behavior, given that most of the people contacted were male and Caucasian. Being discriminated against because of gender, religion, race, or cultural background occurs everywhere much too often. However, I believe that when this phenomenon happens within an academic institution, it is much worse because it demonstrates that faculty members are not able to teach their students - the managers, politicians, or health workers of the future-to respect, take care, and love every human being. Institutions must educate their students to treat all people equally and demonstrate this respect themselves.

Moreover, academic staff would benefit from further information about the needs of international students and the differences between programs. They seemed to take for granted that visiting scholars can ask for a Ph.D. program extension like in the United States, but this is not possible everywhere. As reported also in a study by Dewey and Duff (2009), the authors declared that they would desire "clarity in faculty involvement and roles in internationalization at the institutional level" (p. 501). They noticed, in fact, that at their university in Oregon, "Institutional rationales, concepts, motivations, goals, and desired outcomes regarding internationalization have 
not yet been clearly defined." Ten years have passed after the publication of this study and it seems that many faculty members around the country are still not clear about their role in the internationalization process. A more recent study highlighted the lack of readiness of many universities to engage and support international students (Choudaha, 2016). Therefore, I believe that faculty members should attend workshops or seminars annually in order to gain more technical information about the internationalization process or about the typical struggles of international students. For this reason, their role would be more supportive and helpful. Even though there are specific offices and employees that may take care of this, every single member of an institution can make the difference. Finally, professors are always the first to be contacted by international students; thus they should be able to answer their questions or manage some situations.

In conclusion, becoming a graduate visiting scholar (no degree-seeking) seems to be very difficult and takes too long to work for many programs, even in cases with initial success. Applications and bureaucracy should be easier and faster, and major support is required as reported also in other studies (Fischer, 2017; Skinner, 2009). In 2007, the Human Resources No.110-73 (cited in Hefner-Babb \& Khoshlessan, 2018). affirmed that the United States of America has always tried to attract international students, yet it seems that faculty members are burdened by the idea of supervising international students and, thus, are not willing to sponsor or support them or feel too busy to meet their needs (Dewey \& Duff, 2009; Felton \& Harrison, 2017; Lee et al., 2019), despite that other studies state the opposite (e.g., Jin \& Schneider, 2019). My experience was with a small number of subjects from only six states of the United States, limiting the generalizability. However, it has been shown also that if an institution welcomes and supports a scholar is largely dependent on faculty willingness (Jin \& Schneider, 2019). Finally, hosting a talented Ph.D. visiting student after a successful application and admission should be seen as an ethical obligation despite the personal problems of faculty. In order to avoid similar future situations, it would be useful that if two supervisors were chosen during the application or sponsorization process, or that a backup sponsor could be identified. Furthermore, I would recommend the presence of a mediator between the hosting and the home school or between the school and the international student, so that he can ease the process and help both parties to meet their needs.

Regarding my current situation, I still do not know if I am able to pursue my Ph.D. My aim is to become a Clinical Ethics Consultant and to attend a post-doctoral fellowship in Clinical Ethics, a role not present yet in my country and still not very developed across Europe. I would like to continue my experience as a researcher as well. Thus, in order to achieve these goals, I should continue my education in the United States, where the Clinical Ethics Consultant's role has been established since the 1970s. If I am not able to, it 
means that I will have to renounce my dream because "the land where you can realize all your dreams" may not support me, the same country that argues to have as a mission "to welcome talented international students and provide opportunities for them to study, teach, and conduct research" (Hefner-Babb \& Khoshlessan, 2018, page. 1929).

\section{REFERENCES}

Chao, C., Hegarty, N., Angelidis, J., \& Lu, V. (2017). Chinese students' motivations for studying in the United States. Journal of International Students, 7(2), $257-269$.

Choudaha, R. (2016). Campus readiness for supporting international student success. Journal of International Students, 6(4), I-V.

Dewey, P., \& Duff, S. (2009). Reason before passion: Faculty views on internationalization in higher education. Higher Education, 58(4), 491504. doi:10.1007/S10734-009-9207-Z

Dwyer, M. M. (2004). More is better: The impact of study abroad program duration. The Interdisciplinary Journal of Study Abroad, 10, 151-163.

Felton, K., \& Harrison, G. (2017). Supporting inclusive practicum experiences for international students across the social sciences: Building industry capacity. Higher Education Research \& Development, 36(1), 88-101.

Fischer, K. (2017). Even in limbo, the travel ban reverberates. Chronicle of Higher Education. https://www.chronicle.com/article/Even-in-Limbo-Trumps/239864?cid=at\&utm source=naicu

Hefner-Babb, T., \& Khoshlessan, R. (2018). Iranian student experience pursuing admission to universities in the United States. Journal of International Students, 8(4), 1926-1940.

Institute of International Education (IIE). (2017). Interest among international students holds steady for fall 2017. Retrieved from: https://www.iie.org/Why-IIE/Announcements/2017/07/2017-07-06-IIESurvey-of-College-Admissions-International-Students-Fall-2017

Jin, L., \& Schneider, J. (2019). Faculty views on international students: A survey study. Journal of International Students, 9(1), 84-96. https://doi.org/10.32674/jis.v9i1.268

Lee, D. A., Haines, T. P., Maneephong, S., \& Zeng, Q. (2019). Barriers to fieldwork placements for international higher degree students: A Systematic literature review. Australian Journal of Career Development, 28(3) 197-211.

Marks, J., Yeager, C., Jr., Gatrell, J., \& Bennett, J. (2018). The institutional determinants of internationalization: The cases of study abroad participation and international student enrollment. Journal of International Students, 8(4), 1591-1612. https://doi.org/10.32674/jis.v8i4.220

Naffziger, D. W., Bott, J. P., \& Mueller, C. B. (2008). Factors influencing study abroad decisions among colleges of business students. International Business: Research, Teaching, and Practice, 2(1), 39-52. 
Nikias, M. (2008). Attracting foreign students to America offers more advantages. http://www.usc.edu/academe/faculty/private/8009/nikias_attracting_foreig $\mathrm{n}$ students to america offers more advantages 2.pdf

Pascarella, E. T., Palmer, B., Moye, M., \& Pierson, C. T. (2001). Do diversity experiences influence the development of critical thinking? Journal of College Students Development, 42(3), 257-271.

Rose-Redwood, C., \& Rose-Redwood, R. (2017). Rethinking the politics of the international student experience in the age of Trump. Journal of International Students, 7(3), I-IX. https://doi.org/10.32674/jis.v7i3.201

Skinner, K. (2009). International students: The global commerce of higher education. http://education.stateuniversity.com/pages/2129/internationalstudents.htm

Springer, S. P., Reider, J., \& Morgan, J. V. (2017). Admission matters: What students and parents need to know about getting into college ( $4^{\text {th }} \mathrm{ed}$.). Jossey-Bass.

Williams, T. R. (2005). Exploring the impact of study abroad on students' intercultural communication skills: Adaptability and sensitivity. Journal of Studies in International Education, 9(4), 356-371. https://doi.org/10.1177/1028315305277681

Zawacki-Richter, O., \& Bedenlier, S. (2015). Internationalization of higher education and the impacts on academic faculty members. Journal of Studies In International Education, 10, 185-201.

MARGHERITA DAHO', LCP, M.S., M.A., Ph.D. student, at the Department of Cognitive Sciences, Psychology, Educational and Cultural Studies (COSPECS), University of Messina, Italy; Her major research interests lie in the area of moral reasoning, clinical ethics, end-of-life period, and clinical and health psychology. Email: mdaho@unime.it. 